\title{
Changes in soil cryptogamic communities in tropical Ecuadorean páramos
}

\author{
Y. González 1,3, G. Aragón², A. Benítez ${ }^{1}$ and M. Prieto² \\ ${ }_{1}$ Departamento de Ciencias Biológicas, Sección de Ecología y Sistemática, Universidad Técnica Particular de Loja, \\ San Cayetano Alto s/n, Loja, Ecuador \\ 2 Departamento de Biología, Geología, Física y Química Inorgánica, Área de Biodiversidad y Conservación ESCET, \\ Universidad Rey Juan Carlos, Móstoles, E- 28933, Madrid, Spain \\ ${ }_{3}^{3}$ Corresponding author. E-mail: xygonzalez@utpl.edu.ec,phone: +593 992626460
}

Keywords: Altitude, Bryophytes, Cladoniaceae, Climatic conditions, Lichens, Plant cover, Rainfall, Slope.

\begin{abstract}
Altitudinal gradients involve macroclimatic changes that can affect the diversity of several organisms. We tested the effects of elevation and small-scale variables on the diversity and composition of terricolous communities (lichens and bryophytes) in five páramos in southern Ecuador. The altitudinal range considered (from 2700 to $4000 \mathrm{~m}$ a.s.1.) is associated with changes in rainfall, temperature and irradiance. At each páramo, forty $40 \mathrm{x} 40 \mathrm{~cm}^{2}$ sample plots were randomly selected in similar areas of vegetation (grass páramo) and conservation status. The presence/absence and cover of lichens and bryophytes were recorded in 200 sample plots. A total of 90 species (46 lichens and 44 bryophytes) were identified. Our results showed that total species richness, lichen and bryophyte richness, Simpson's inverse and Shannon's index were related to elevation and slope. Nevertheless, the response to elevation was dependent on the organism considered. Thus, meanwhile lichens had their maximum richness at the highest elevation (3930 $\mathrm{m}$ a.s.1.), bryophytes had a maximum peak at middle elevation (3300 $\mathrm{m}$ a.s.1.). Species composition also differed significantly among the five páramos, especially in bryophytes. We conclude that differences in the elevation of these páramos and small-scale variables such as slope significantly affect the diversity and composition of terricolous communities
\end{abstract}

Nomenclature and identification for lichens: Lumbsch 1989, Goward et al. 1995, Sipman 1997, 2002, Ahti 2000, Brodo et al. 2001, Nash et al. 2002, 2004, Smith et al. 2009, Rivas Plata et al. 2010, Moncada 2012, Lücking et al. 2013, Rincón-Espitia and Mateus 2013.

Nomenclature and identification for bryophytes: Churchill and Linares 1995, Gradstein et al. 2001 and Gradstein and Costa 2003.

Abbreviation: PERMANOVA—Permutational Analysis of Variance.

\section{Introduction}

Understanding the relationship between elevation and species richness has been a general challenge addressed over the past years. In various organisms and geographical areas, main findings point to a decrease in species richness with increasing elevation (Terborgh 1977, Stevens 1992) or a humped-shaped relationship, with a peak in richness at intermediate elevations (Rahbek 1997, Grytnes and Vetaas 2002, Krömer et al. 2005, Brehm et al. 2007, Baniya et al. 2010). Apart from the environmental changes associated with the altitude, biotic, abiotic and historical factors have also been discussed as having a possible impact on species richness along these gradients (Rahbek 1995, Lomolino 2001).

The published studies about species richness and diversity along elevational gradients are strongly biased towards plants and temperate zones (Brehm et al. 2007). In tropical areas altitudinal gradients have been considered in several diversity studies (Terborgh 1977, Sipman 1989, Gradstein et al. 1989, Krömer et al. 2005, Brehm et al. 2007, Jankowski et al. 2013). However, very few are focused exclusively on the study of altitudinal gradients in high Andean páramo ecosystems (Sipman 1989, Keating 1999, Sklenář and Ramsay 2001, Paredes 2006, Sklenář et al. 2010). Páramo ecosystems provide several ecological functions and environmental services such as the regulation of hydrology, protection from erosion, carbon storage and its function as a biological corridor for many species of flora and fauna (Hofstede et al. 2003, Buytaert et al. 2006). Furthermore, páramos host the richest high mountain flora of the world (Smith and Cleef 1988), being considered as a hotspot within a hotspot (Myers et al. 2000) with a high endemicity and with the fastest diversification rates of all hotspots (Madriñán et al. 2013). In these páramos, climatic factors, orography, age of the substrate, land use or dispersal have an influence on the diversity patterns (Acosta-Solís 1984, Luteyn 1992, Sklenář et al. 2010).

Terricolous cryptogams are an important fraction of the high diversity of these ecosystems and also play a relevant role in terms of biomass, carbon/nutrient cycling, ecosystem functioning, water-storage and soil cohesion (Pérez 1997, 
Gradstein and Holz 2005, Rai et al. 2010). However, very few studies have focused on their response to altitude in the Neotropics (Sipman 1989, Van Reenen and Gradstein 1983, Gradstein et al. 1989, Kessler 2000) and even less in páramo ecosystems (Paredes 2006).

Although it has been reported that the diversity of soil lichens and bryophytes is structured along an altitudinal gradient in different geographic regions and ecosystems, there is no clear pattern of changes in the richness and diversity in relation to elevation. Thus, different responses have been found: increases in richness or cover with altitude, decreases, humped relationships with maximum richness at intermediate altitudes or different responses for bryophytes and lichens separately (Thompson et al. 2005, Bruun et al. 2006, Grytnes et al. 2006, Paredes 2006, Grau et al. 2007, Tusiime et al. 2007, Stehn et al. 2010, Vittoz et al. 2010, Sun et al. 2013, Rai et al. 2015). Differences found in these responses could be related to environmental variables operating at different scales. Thus, local factors such as slope, aspect, soil properties $(\mathrm{pH}$, texture, acidity, electrical conductivity), micronutrients, moisture, herb and shrub cover, or land use intensity also have a significant effect on the ground communities (Ponzetti and McCune 2001, Bowker et al. 2005). Additionally it has highlighted the role of biotic interactions structuring these communities, affected by the availability of resources like space, nutrients or water (Maestre et al. 2008, 2009, Bowker et al. 2010). Other factors explaining the different patterns found could be related to different scales of the studies, diverse methodologies used or differences in the studied organisms (Grau et al. 2007).

Altitudinal gradients within the tropics constitute an important tool to improve the knowledge of ecosystem ecology and function, as well as to determine its influence on diversity and species distribution (Malhi et al. 2010). In this context, the main objective of our study was to ascertain whether elevation influences the diversity and composition of terricolous cryptogamic communities of five páramos in southern Ecuador. Specifically, we aimed to address the following questions: (1) Are richness and composition of lichens and bryophytes structured along an altitudinal gradient? (2) Do lichens and bryophytes respond in the same way to these differences in elevation and the ecological factors associated? (3) Which other factors affect these communities?

\section{Materials and methods}

\section{Study site}

The study area included five páramos located in Loja (Punzara, Loma del Oro, Cajanuma and Jimbura) and Azuay (El Cajas) provinces (southern Ecuador) (Fig. 1). The selected páramos range between 2700 and $4000 \mathrm{~m}$ above sea level (Table 1). Punzara is considered an azonal páramo due to the influence of strong winds. The vegetation is characterized by grasses with some shrubs scattered and small herbs (León-Yánez 2000). The most important genera of grasses are Calamagrostis, Festuca and Stipa (León-Yánez 2000).

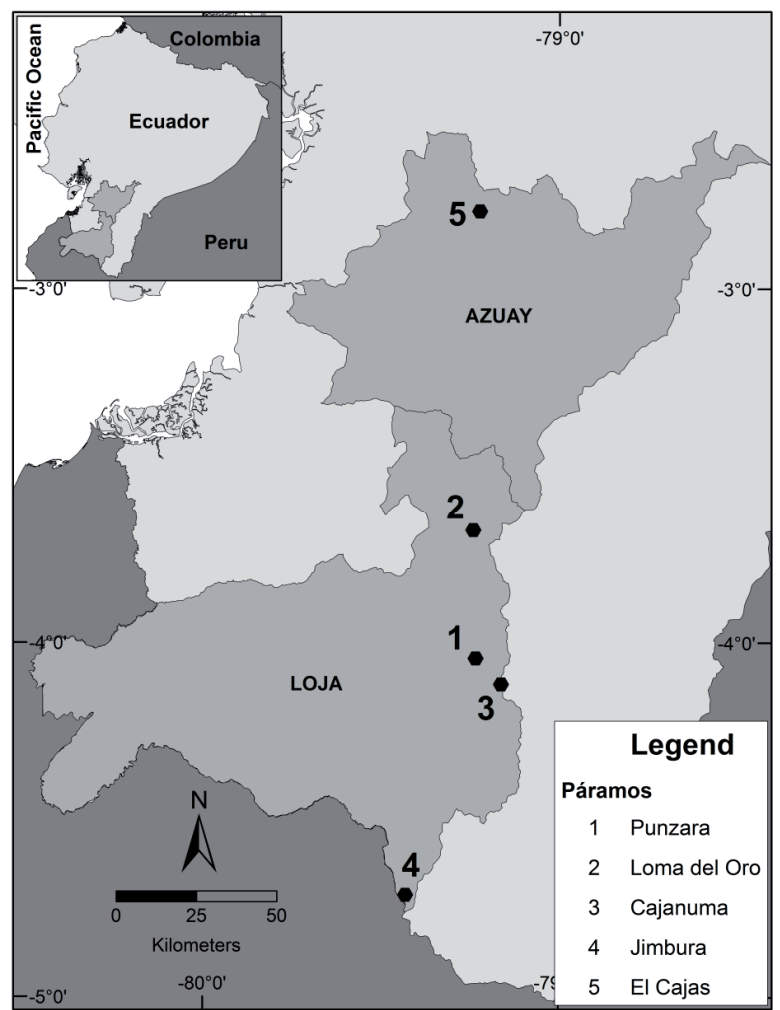

Figure 1. Location of the five studied páramos in Ecuador.

Cajanuma, El Cajas, Jimbura and Loma del Oro correspond to grass páramo (Cueva and Chalán 2010, Hofstede et al. 2002). Main genera dominating in these areas are Calamagrostis, Carex, Festuca and Paspalum (León-Yánez 2000). Cajanuma is the only one covered by montane forest close to the páramo and below $3000 \mathrm{~m}$. In the five sampled localities some other common species were Loricaria thuyoides (Lam.) Sch. Bip., Lycopodium clavatum L., L. vestitum Desv., Oreobolus sp. and Puya sp.

The climate in the Ecuadorian páramos is generally cold and humid throughout the year, with extremely changing daily temperatures. In the five localities, the mean annual temperatures range from $5{ }^{\circ} \mathrm{C}$ to $14^{\circ} \mathrm{C}$ (Table 1) and annual rainfall between 936-1440 mm (Table 1). The soils in southern Ecuador páramo ecosystems are highly variable, coming from Paleozoic metamorphic rocks, except in El Cajas, where the soils are enriched with volcanic ash deposits (Podwojewski and Poulenard 2000).

The five studied páramos are similar both in plant composition and conservation status, corresponding to grass páramo of the Ecuadorian southern region with similar floristic composition which differs from the northern Ecuadorian páramos (Valencia et al. 1999, Hofstede et al. 2002).

\section{Sampling design and data collection}

Undisturbed zones were selected within each páramo with the same plant composition and well developed cryptogamic communities ( 3 ha approximately). Within these zones, forty plots of $40 \times 40 \mathrm{~cm}^{2}$ were randomly placed, with a minimum 
Table 1. Environmental variables of the five studied páramos.

\begin{tabular}{|c|c|c|c|c|c|c|c|c|}
\hline No. & Name & $\begin{array}{c}\text { Elevation } \\
(\mathrm{m} \text { a.s.1.) } \\
(\min -\max )\end{array}$ & $\begin{array}{c}\text { Slope }\left({ }^{\circ}\right) \\
\text { mean } \pm \\
\text { S.E. }\end{array}$ & $\begin{array}{c}\text { Aspect }\left(^{\circ}\right) \\
\text { mean } \pm \\
\text { S.E. }\end{array}$ & $\begin{array}{l}\text { Annual pre- } \\
\text { cipitation } \\
(\mathrm{mm})\end{array}$ & $\begin{array}{l}\text { Average } \\
\text { temp. }{ }^{\mathrm{a}} \\
\left({ }^{\circ} \mathrm{C}\right)\end{array}$ & $\begin{array}{l}\text { Min. } \\
\text { temp. }{ }^{\text {a }} \\
\left({ }^{\circ} \mathrm{C}\right)\end{array}$ & $\begin{array}{l}\text { Max. } \\
\text { temp. } \\
\left({ }^{\circ} \mathrm{C}\right)\end{array}$ \\
\hline 1 & Punzara & $2770(2700-2900)$ & $33 \pm 2.3$ & $0.15 \pm 0.11$ & 936 & 14 & 9 & 18 \\
\hline 2 & $\begin{array}{l}\text { Loma del } \\
\text { Oro }\end{array}$ & $3245(3100-3300)$ & $25 \pm 2.6$ & $-0.11 \pm 0.11$ & 1256 & 10 & 5 & 15 \\
\hline 3 & Cajanuma & $3337(3300-3400)$ & $12 \pm 1.4$ & $0.06 \pm 0.11$ & 1295 & 10 & 5 & 16 \\
\hline 4 & Jimbura & $3450(3400-3500)$ & $17 \pm 2$ & $-0.08 \pm 0.11$ & 1140 & 7 & 2 & 14 \\
\hline 5 & El Cajas & $3930(3850-4000)$ & $22 \pm 1.7$ & $-0.03 \pm 0.10$ & 1440 & 5 & 2 & 10 \\
\hline
\end{tabular}

a Source: Ministerio del Ambiente, Ecuador, 2010.

distance of $1 \mathrm{~m}$ between them to avoid spatial autocorrelation (Maestre et al. 2008).

We estimated the cover values of all terrestrial species of lichens and bryophytes in each sampling unit through visual detection and we collected samples for posterior identification. For lichen nomenclature and identification we used the following literature: Lumbsch 1989, Goward et al. 1995, Sipman 1997, 2002, Ahti 2000, Brodo et al. 2001, Nash et al. 2002, 2004, Smith et al. 2009, Rivas Plata et al. 2010, Moncada 2012, Lücking et al. 2013, Rincón-Espitia and Mateus 2013, and for bryophytes we used Churchill and Linares 1995, Gradstein et al. 2001 and Gradstein and Costa 2003.

Additionally, we measured the cover of vascular plants $(\%)$ at plot level and the slope $\left(^{\circ}\right)$ and aspect (compass direction of the slope, cosine transformed) as both are related to microclimatic conditions as irradiance, stability of the substrate, soil temperature or soil moisture (Garcia-Pichel and Belnap 2001). The macroclimatic variables (annual rainfall, mean annual temperature and monthly mean minimum and maximum temperature) at páramo level were provided by the Ministry of Environment of Ecuador (MAE 2010). We considered the minimum temperature important as a limiting factor because páramo ecosystems reach extreme temperatures at night (León-Yánez 2000), affecting growth and development of cryptogams (Kappen 2000, Bramley-Alves et al. 2014). Elevation was obtained with a GPS (Garmin GPS).

\section{Data analyses}

The community variables analyzed were Simpson's and Shannon's indices, Pielou's evenness, total species richness, the richness of lichens and bryophytes separately and the cover and richness of the lichen family Cladoniaceae (i.e., Cladia and Cladonia, which were considered together). Cladoniaceae family was analyzed separately because they are very important components of the terricolous communities within páramos and dominate in these habitats (Ahti 1992). Simpson's and Shannon's indices allow to combine species richness and relative abundance into an estimate of diversity when data from multiple sites exist (Gorelick 2006). Simpson's index is determined by the most dominant species and the Shannon's index assumes that the individuals are selected randomly and that all species are represented in the sample (Magurran 2004). Pielou's evenness is calculated as the ratio between the observed diversity and the maximum diversity (Magurran 2004).

To determine the effect of the macroclimatic (elevation, annual rainfall, mean annual temperature, monthly mean minimum and maximum temperature) and the small-scale factors (slope, aspect and plant cover) on the community variables, we used generalized linear models (GLMs). In order to test non-linear relationships we introduced a quadratic term for the elevation. Elevation showed high correlations with annual rainfall, mean annual temperature and monthly mean minimum and maximum temperatures (Pearson's correlation $\mathrm{r}^{2}>0.800, p<0.05$ in all cases). Thus, in order to prevent multi-collinearity problems, elevation was the only variable at páramo level included in the model. For total richness, richness of lichens, bryophytes and Cladoniaceae we used a Poisson distribution with a "log" link function and for Simpson's inverse, Shannon's index, Pielou's evenness and Cladoniaceae cover we used a Gaussian distribution with "identity" link function. Poisson distribution is usually employed to fit count data, and inspection of our data confirmed that this distribution fitted better than alternative distributions, such as the normal distribution. All statistical analyses were performed in $\mathrm{R}$ version 3.1.1

The composition of soil species of the five páramos was compared using the PRIMER multivariate statistical analysis software version 6.1.11 (Anderson et al. 2008). In this analysis, the experimental design included one factor: páramo (five levels) with 40 replicate units per páramo. The cover data (percentage cover per species) were $\log _{10}(\mathrm{x}+1)$ transformed to downplay the influence of abundant taxa. We used the Bray-Curtis distance measure to test whether the five páramos had significantly different composition of cryptogams and we performed a one-factor permutational multivariate analysis of variance (PERMANOVA) on the cover data. For all tests, we allowed 9999 random permutations under the reduced model. Non-metric multidimensional scaling (NMDS) was used to determine the main factors (elevation, slope, aspect and plant cover) influencing total species composition and lichens and bryophytes composition separately. NMDS ordination was performed using 50 random restarts. We computed the resemblance matrix using the Bray-Curtis dissimilarity index. Values of relative species abundance and environmental variables were then fitted onto the first two axes of 
Table 2. Species richness and exclusive taxa of the five studied páramos.

\begin{tabular}{|c|c|c|c|c|c|c|c|c|c|}
\hline \multirow{3}{*}{ Páramo } & \multirow{3}{*}{$\begin{array}{c}\text { Elevation } \\
\text { (m a.s.1.) }\end{array}$} & \multicolumn{5}{|c|}{ Total taxa } & \multicolumn{3}{|c|}{ Exclusive taxa } \\
\hline & & \multirow{2}{*}{$\begin{array}{c}\text { Total } \\
\text { number }\end{array}$} & \multicolumn{2}{|c|}{ Bryophyte } & \multicolumn{2}{|c|}{ Lichen } & \multirow[b]{2}{*}{ Total } & \multirow{2}{*}{ Bryophyte } & \multirow{2}{*}{ Lichen } \\
\hline & & & $\begin{array}{l}\text { Number of } \\
\text { species }\end{array}$ & $\begin{array}{c}\text { Cover* } \\
(\%)\end{array}$ & $\begin{array}{l}\text { Number of } \\
\text { species }\end{array}$ & $\begin{array}{c}\text { Cover* } \\
(\%)\end{array}$ & & & \\
\hline 1 & 2770 & 19 & 5 & 11 & 14 & 59 & 6 & 1 & 5 \\
\hline 2 & 3245 & 42 & 20 & 33 & 22 & 48 & 10 & 3 & 7 \\
\hline 3 & 3337 & 39 & 28 & 36 & 11 & 61 & 13 & 11 & 2 \\
\hline 4 & 3450 & 31 & 16 & 31 & 15 & 49 & 3 & 2 & 1 \\
\hline 5 & 3930 & 39 & 15 & 24 & 24 & 63 & 14 & 3 & 11 \\
\hline
\end{tabular}

* Average cover for each páramo.
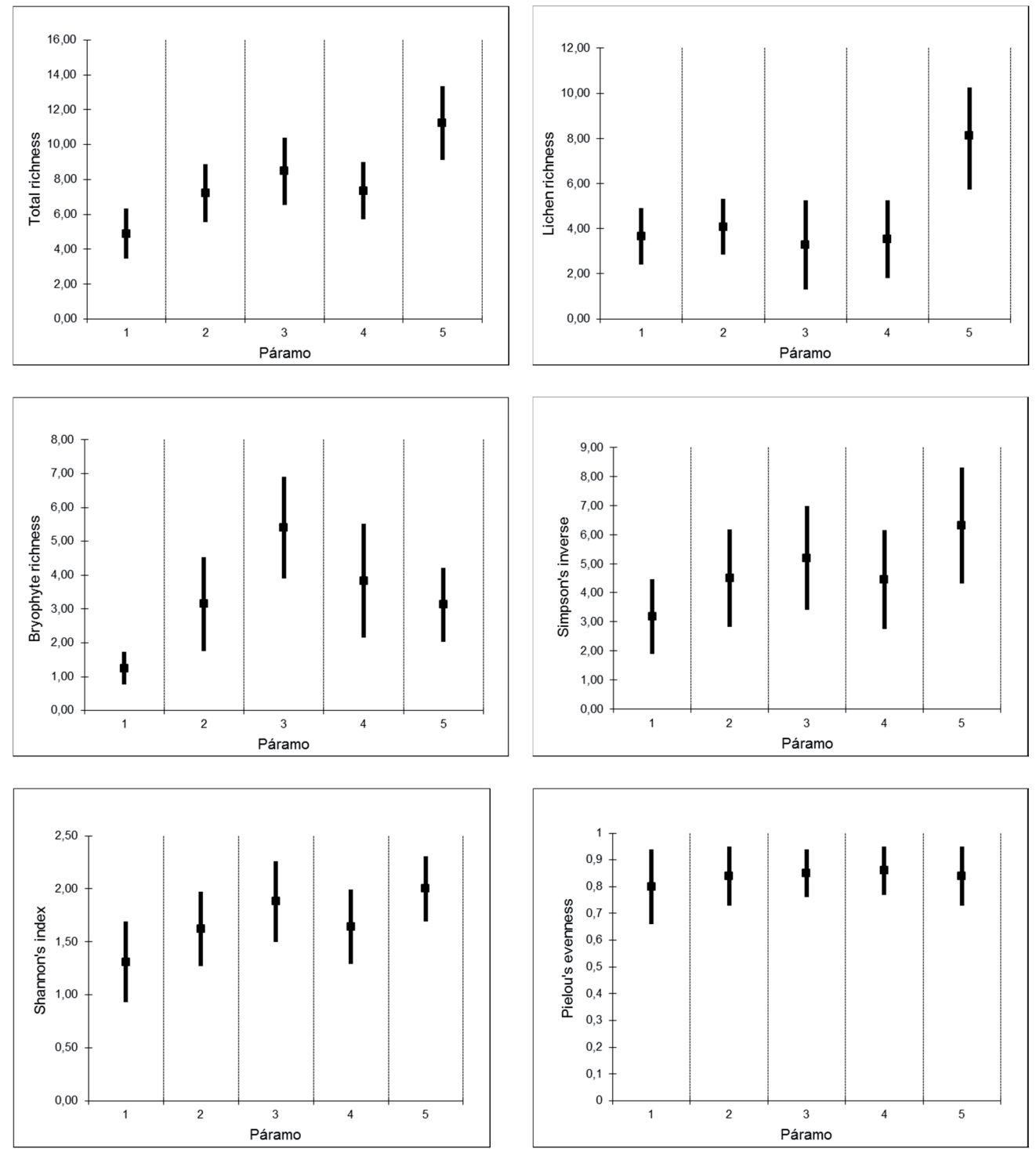

Figure 2. Species richness and diversity patterns in the five studied páramos. Values represent the means $( \pm$ SD) of the 40 plots per páramo. Páramos are arranged according to elevation, so axis X corresponds to an elevation gradient.

the NMDS ordination. For these linear fittings squared correlation coefficients $\left(\mathrm{r}^{2}\right)$ and empirical $p$-values $(p)$ were calculated. Variables with $\mathrm{r}^{2} \geq 0.3$ were considered as correlated. To identify the taxa that contributed most to the similarity and dissimilarity among páramos in the NMDS ordination plot, we used the BVSTEP statistical routine. This routine identifies the smallest subset of species capable of reproducing the differences in community patterns among páramos that were obtained in the NMDS ordination ( $\rho=0.95$, with 100 restarts) (Clarke and Warwick 1998). 
Table 3. Results of the generalized linear models on the community variables. Coef.: coefficient of the variable in the model, S.E.: standard error.

\begin{tabular}{|c|c|c|c|}
\hline & Coef. (S.E.) & $t$-value & $p$-value \\
\hline \multicolumn{4}{|c|}{ Species richness } \\
\hline Elevation & $0.0044(0.0012)$ & 3.657 & 0.0003 \\
\hline Elevation^2 & $-6.1 \times 10^{-7}\left(1.8 \times 10^{-7}\right)$ & -3.454 & 0.0006 \\
\hline Plant cover & $0.0017(0.0014)$ & 1.199 & 0.2306 \\
\hline Slope & $-0.0056(0.0020)$ & -2.777 & 0.0055 \\
\hline Aspect & $0.0293(0.0376)$ & 0.778 & 0.4365 \\
\hline \multicolumn{4}{|c|}{ Lichen richness } \\
\hline Elevation & $-0.0035(0.0016)$ & -2.211 & 0.0270 \\
\hline Elevation^2 & $5.4 \times 10^{-7}\left(2.3 \times 10^{-7}\right)$ & 2.337 & 0.0194 \\
\hline Plant cover & $0.0010(0.0018)$ & 0.549 & 0.5828 \\
\hline Slope & $-0.0051(0.0028)$ & -1.846 & 0.0649 \\
\hline Aspect & $0.0457(0.0519)$ & 0.882 & 0.3781 \\
\hline \multicolumn{4}{|c|}{ Bryophyte richness } \\
\hline Elevation & $0.0156(0.0020)$ & 7.707 & $<0.001$ \\
\hline Elevation^2 & $-2.3 \times 10^{-6}\left(2.9 \times 10^{-7}\right)$ & -7.593 & $<0.001$ \\
\hline Plant cover & $0.0024(0.0021)$ & 1.126 & 0.2603 \\
\hline Slope & $-0.0060(0.0030)$ & -2.008 & 0.0447 \\
\hline Aspect & $0.0108(0.0547)$ & 0.196 & 0.8443 \\
\hline \multicolumn{4}{|c|}{ Simpson's inverse } \\
\hline Elevation & $0.0122(0.0060)$ & 2.042 & 0.0425 \\
\hline Elevation^2 & $1.6 \times 10^{-6}\left(8.8 \times 10^{-7}\right)$ & -1.833 & 0.0683 \\
\hline Plant cover & $0.0127(0.0071)$ & 1.793 & 0.0745 \\
\hline Slope & $-0.0267(0.0101)$ & -2.638 & 0.0090 \\
\hline Aspect & $0.1157(0.1984)$ & 0.583 & 0.5603 \\
\hline \multicolumn{4}{|c|}{ Shannon's index } \\
\hline Elevation & $0.0038(0.0012)$ & 3.186 & 0.0017 \\
\hline Elevation^2 & $-5.1 \times 10^{-7}\left(1.8 \times 10^{-7}\right)$ & -2.931 & 0.0038 \\
\hline Plant cover & $0.0030(0.0014)$ & 2.165 & 0.0316 \\
\hline Slope & $-0.0066(0.0020)$ & -3.265 & 0.0013 \\
\hline Aspect & $0.0377(0.0394)$ & 0.957 & 0.3396 \\
\hline \multicolumn{4}{|c|}{ Pielou's evenness } \\
\hline Elevation & $0.0003(0.0003)$ & 0.883 & 0.3785 \\
\hline Elevation^2 & $-4.0 \times 10^{-8}\left(5.0 \times 10^{-8}\right)$ & -0.802 & 0.4235 \\
\hline Plant cover & $0.0008(0.0004)$ & 1.950 & 0.0526 \\
\hline Slope & $-0.0010(0.0006)$ & -1.745 & 0.0825 \\
\hline Aspect & $0.0039(0.0112)$ & 0.348 & 0.7279 \\
\hline
\end{tabular}

$p$-values $<0.05$ are considered significant and marked in bold.

\section{Results}

We recorded 46 lichens belonging to 16 families and 44 bryophytes belonging to 24 families in the five studied páramos (Appendix 1). The total number of species ranged from 19 in Punzara páramo to 42 in Loma del Oro (Table 2). The number of exclusive taxa ranged from 3 in Jimbura to 14 at the highest elevation (El Cajas) (Table 2, Appendix 1). Lichens dominated in all sampling units, with an average cover between $48 \%$ and $63 \%$, while bryophytes cover never exceeded of a $36 \%$ (Table 2). The family Cladoniaceae was the most predominant and the best represented lichen family with 20 taxa belonging to the two genera Cladia ( 2 species) and Cladonia (18 species) (Appendix 1). Members of the Cladoniaceae appeared in $98 \%$ of plots, showing an average cover of about $50 \%$. The predominant species were Cladia aggregata and Cladia fuliginosa, which were presented in 142 and 114 plots, respectively, out of 200 plots in total (Appendix 1).

We found significant relationships between the elevation (including the quadratic term) and all community variables, except Pielou's evenness (Fig. 2, Table 3). The slope had a negative and significant effect on the species richness, bryophyte richness, Simpson's inverse, Shannon's index and the Cladoniaceae cover (Tables 3 and 4).

A significant component of the variation of the species composition was associated with páramo (Table 5). The NMDS ordination for the total species composition showed that the highest variability was explained by the elevation (Axis 1: -0.36 ; Axis $2: 0.93 ; \mathrm{r}^{2}=0.38 ; p=0.000999$ ). This variable was weakly correlated to lichen (Axis $1:-0.99$; Axis $\left.2:-0.03 ; \mathrm{r}^{2}=0.08 ; p=0.000999\right)$ and bryophyte composition (Axis 1: -0.24 ; Axis $2:-0.97 ; \mathrm{r}^{2}=0.21 ; p=0.000999$ ) (Fig. 
Table 4. Results of the generalized linear models on the Cladoniaceae richness and cover. Coef.: coefficient of the variable in the model. S.E.: standard error.

\begin{tabular}{lccc}
\hline & Coef. (S.E.) & $t$-value & $p$-value \\
\hline Cladoniaceae richness & & & \\
\hline Elevation & $0.0003(0.0003)$ & 1.140 & 0.2556 \\
Plant cover & $0.0042(0.0052)$ & 0.803 & 0.4230 \\
Slope & $-0.0138(0.0070)$ & -1.955 & 0.0520 \\
Aspect & $0.2356(0.1459)$ & 1.615 & 0.1080 \\
\hline Cladoniaceae cover & & & \\
\hline Elevation & $0.0013(0.0044)$ & 0.289 & 0.7729 \\
Plant cover & $-0.0895(0.0831)$ & -1.076 & 0.2832 \\
Slope & $-0.2484(0.1129)$ & -2.201 & $\mathbf{0 . 0 2 9 0}$ \\
Aspect & $1.2107(2.3369)$ & 0.518 & 0.6050 \\
\hline
\end{tabular}

Table 5. Results of one-factor PERMANOVA analysis by páramo ecosystem. Values for the total composition, lichen composition and bryophyte composition. Degrees of freedom (df); mean sum of squares (MS); F value by permutation (Pseudo-F); significance level $(P)$; coefficient of variation $(\mathrm{CV})$.

\begin{tabular}{lrrrrr}
\hline \multicolumn{1}{c}{ Source } & df & MS & Pseudo-F & P & CV (\%) \\
\hline Total & & & & & \\
\hline Páramo & 4 & 50453 & 23.738 & 0.0001 & 34.759 \\
Residual & 195 & 2125.4 & & & 46.102 \\
\hline Lichens & & & & & \\
\hline Páramo & 4 & 30863 & 12.868 & 0.0001 & 26.676 \\
Residual & 195 & 2398.4 & & & 48.974 \\
\hline Bryophytes & & & & & \\
\hline Páramo & 4 & 84177 & 44.917 & 0.0001 & 45.36 \\
Residual & 195 & 1874 & & & 43.29 \\
\hline
\end{tabular}

3). The NMDS ordination showed a clear separation between páramos for total and bryophyte composition (Fig. 3A-C). Although significant, the correlations were weak $\left(\mathrm{r}^{2}<0.15\right)$ for the remaining variables (slope, aspect and plant cover). Ninety-five percent of the variation in the NMDS ordination was explained by ten taxa. Of the ten species identified by the BVSTEP routine six were bryophytes (Breutelia tomentosa, Campylopus richardii, Leptodontium sp., Polytrichum juniperidium, Rhacocarpus purpurascens and Racomitrium lanuginosum) and four were lichens (Cladia aggregata, $C$. fuliginosa, Cladonia arbuscula subsp. boliviana and C. calycantha). When these species were excluded, the next-best model contained 22 species, which explained $90 \%$ of the observed pattern.

\section{Discussion}

In this study we found evidence of changes in the richness, diversity and composition of soil cryptogamic communities, comparing for the first time páramo ecosystems (grass páramo) situated at different altitudes.

Main changes are related to elevation and slope. However, when we consider lichens and bryophytes separately, we found different and contrasting patterns with elevation.
Meanwhile lichen richness is maximum at the highest elevation, bryophyte richness showed a hump-shaped relationship. Several authors found similar patterns with a higher richness of lichens at elevations above $3000 \mathrm{~m}$ (Sipman 1989, Paredes 2006, Baniya et al. 2010) and the highest diversity at middle elevations for bryophytes (Grau et al. 2007, Sun et al. 2013), although these studies included different ecosystems at different altitudes.

As the studied páramos are similar in plant composition and disturbance level, differences in altitude might rather reflect a gradient in precipitation, temperature and irradiance, with a trend showing an increase of precipitation and irradiance (Kessler 2002), and a decrease in mean annual temperature with altitude. Thus, differences observed in the patterns for different groups along the same gradient may be attributed to different physiological responses to the changing environmental conditions (Bhattarai and Vetaas 2003, Ah-Peng et al. 2012). Although bryophyte richness usually increases with humidity (Sun et al. 2013), the highest species richness was not found in the páramo with the highest rainfall, but instead at middle altitudes, with less rainfall. In general terms, with increasing altitude, the substrate tends to dry faster by the more intense solar radiation meanwhile in the lower elevation, a similar pattern occurs with the raise in temperature (Vittoz et al. 2010), increasing the evapotranspiration and 

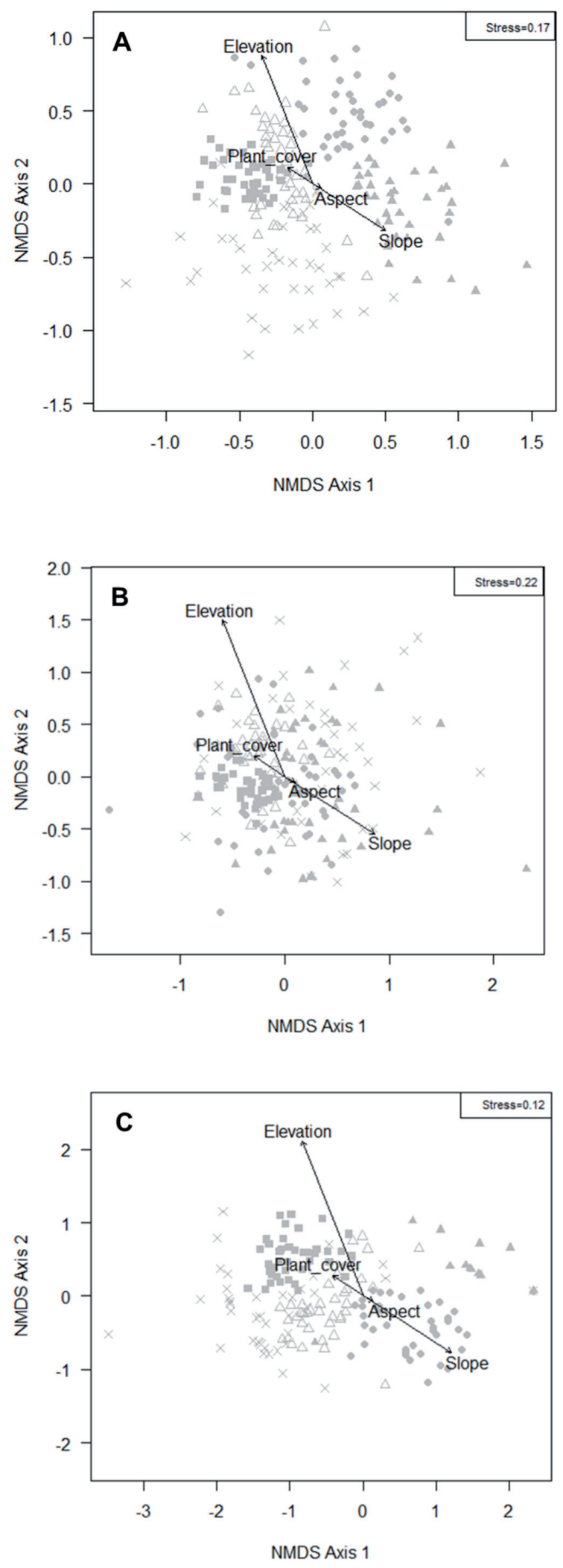

Figure 3. Non-metric multidimensional scaling analysis for species composition of sampled units (plots) in the five studied páramos: Punzara $(\boldsymbol{\Delta})$, Loma del Oro $(\times)$, Cajanuma $(\square)$, Jimbura $(\triangle)$ and El Cajas (•). (A) Total species composition; (B) lichen composition; (C) bryophyte composition. making the air drier. Thus, dessication and air temperature may be affecting species of bryophytes that only survive in more favorable sites situated at middle elevations (Walker et al. 2006, Vittoz et al. 2010, Sun et al. 2013). The highest bryophyte richness found in Cajanuma páramo (at middle elevation) was also associated with an increase of the number of exclusive species (11 exclusive species). This highest richness could also be related to the proximity of montane forests that can serve as a source of species to colonize the nearby páramo.

On the other hand, lichen richness was maximum at the highest elevation, with more precipitation, less average temperature and higher inputs of solar radiation (Kessler 2002). Certain lichens show preferences for high light levels, adjusting their physiology to high light intensities by increasing thallus thickness or the concentration of protective pigments (Gauslaa and Solhaug 2001, Kranner et al. 2008). Moreover, lichens possess several mechanisms assuring cell functioning at low temperatures (Barták et al. 2007). The increase in lichen richness at higher altitudes has been previously found in Paredes (2006) in páramos but different patterns have also been found including broader altitudinal ranges and different ecosystems (Baniya et al. 2010, Vittoz et al. 2010, Rai et al. 2015). Although the lichen family Cladoniaceae is an important component of the páramo communities, we did not find the same altitudinal pattern as in the total lichen richness. Soto-Medina (2013) found two peaks in the Cladoniaceae at 0-1000 m and 2000-3000 m; however, these results are not fully comparable since the altitude considered and the geographic range were much greater.

Another significant variable structuring these communities at all levels (total species, bryophytes, lichens and Cladoniaceae richness and diversity) is the slope, showing an inverse relationship. Slope is related to the stability of the substrate, radiation levels, soil temperature and soil moisture (Garcia-Pichel and Belnap 2001). Thus, microclimatic conditions related to the slope are affecting richness and composition of terricolous communities, a fact that has been demonstrated for bryophytes and lichens separately (Hauck et al. 2007, Mandl et al. 2009).

The composition of terricolous communities in Ecuadorian páramos is also correlated to the elevation, with a stronger pattern in the bryophytes. This evidences the remarkable influence of environmental variables related to differences in elevation (temperature, solar irradiation, humidity, rainfall) on the structure of these communities. Small scale variables at the páramo level, such as slope or plant cover, also influence the composition of terricolous communities. Although other studies (e.g., Sipman 1989) found a different floristic zonation with altitude, they compared different ecosystems (e.g., superpáramo, páramo, montane forest) and different substrates (trees, soils, rocks), contrary to this study in which we found floristic differences comparing the same type of habitat (grass páramo) and substrate (soils).

We therefore conclude that elevation and slope are important factors affecting the diversity and composition of terricolous communities of tropical páramos, probably related 
to changes in rainfall, humidity, temperature and irradiance. Patterns of response to elevations were different in lichens and bryophytes. The maximum lichen richness was found at the highest elevation. For bryophytes, a humped relationship between the amount of species and elevations below $4000 \mathrm{~m}$ a.s.l. was found, probably linked to the less hospitable climate at higher and lower altitudes or the proximity of more suitable areas serving as a source of species. Many factors such as temperature, rainfall, radiation, soil conditions and human disturbance should be assessed along elevational gradients in páramo ecosystems to gain better understanding of diversity and composition of lichens and bryophytes in these ecosystems.

Acknowledgments: Financial support for this study was received from the Universidad Técnica Particular de Loja (UTPL) and a scholarship to the first author provided by Secretaría Nacional de Educación Superior, Ciencia, Tecnología e Innovación (SENESCYT) of Ecuador. We also thank A. R. Burgaz for helping in species identification and M. de la Cruz for comments in the manuscript and help with analyses.

\section{References}

Acosta-Solís, M. 1984. Los páramos andinos del Ecuador. Publicaciones científicas MAS, Quito.

Ah-Peng, C., N. Wilding, J. Kluge, B. Descamps-Julien, J. Bardat, M. Chuah-Petiot, D. Strasberg and T.A.J. Hedderson. 2012. Bryophyte diversity and range size distribution along two altitudinal gradients: continent vs. island. Acta Oecol. 42: 58-65.

Ahti, T. 1992. Biogeographic aspects of Cladoniaceae in the páramos. In: H. Balslev and J.L. Luteyn (eds.), Páramo: An Andean Ecosystem under Human Influence. Academic Press, London. pp. 111-117.

Ahti, T. 2000. Cladoniaceae. Flora Neotropica Monograph No. 78. New York Botanical Garden Press, New York.

Anderson, M.J., R.N. Gorley and K.R. Clarke. 2008. PERMANOVA+ for PRIMER: guide to software and statistical methods. PRIMER-E, Plymouth, United Kingdom.

Baniya, C.B., T. Solhøy, Y. Gauslaa and M.W. Palmer. 2010. The elevation gradient of lichen species in Nepal. Lichenologist 42: 83-96.

Barták, M., P. Váczi, J. Hájek and J. Smykla. 2007. Low-temperature limitation of primary photosynthetic processes in Antarctic lichens Umbilicaria antarctica and Xanthoria elegans. Polar Biol. 31: 47-51.

Bhattarai, K.R. and O.R. Vetaas. 2003. Variation in plant species richness of different life forms along a subtropical elevation gradient in the Himalayas, east Nepal. Glob. Ecol. Biogeogr. 12: 327-340.

Bowker, M.A., J. Belnap, D.W. Davidson and S.L. Phillips. 2005. Evidence for micronutrient limitation of biological soil crusts: importance to arid-lands restoration. Ecol. Appl. 15: 1941-1951.

Bowker, M.A., S. Soliveres and F.T. Maestre. 2010. Competition increases with abiotic stress and regulates the diversity of biological soil crusts. J. Ecol. 98: 551-560.

Bramley-Alves, J., D.H. King, S.A. Robinson and R.E. Miller. 2014. Dominating the Antarctic environment: Bryophytes in a time of change. In: D.T. Hanson and S.K. Rice (eds.), Photosynthesis in
Bryophytes and Early Land Plants. Springer, Netherlands. pp. 309-324.

Brehm, G., R.K. Colwell and J. Kluge. 2007. The role of environment and mid-domain effect on moth species richness along a tropical elevational gradient. Glob. Ecol. Biogeogr. 16: 205-219.

Brodo, I., S. Duran and S. Sharnoff. 2001. Lichens of North America. Yale University Press, London.

Bruun, H.H., J. Moen, R. Virtanen, J-A Grytnes, L. Oksanen and A. Angerbjörn. 2006. Effects of altitude and topography on species richness of vascular plants, bryophytes and lichens in alpine communities. J. Veg. Sci. 17: 37-46.

Buytaert, W., V. Iñiguez, R. Celleri, D. De Bièvre, G. Wyseure and J. Deckers. 2006. Analysis of the water balance of small páramo catchments in south Ecuador. In: J. Krecek and M. Haigh (eds.), Environmental Role of Wetlands in Headwaters. Springer, Berlin. pp. 271-281.

Churchill, S.P. and E. Linares. 1995. Prodromus Bryologiae NovoGranatensis. Introducción a la Flora de Musgos de Colombia. Biblioteca José Jerónimo Triana, Santafé de Bogotá.

Clarke, K.R. and R.M. Warwick. 1998. Quantifying structural redundancy in ecological communities. Oecologia 113: 278-289.

Cueva, J. and L. Chalán. 2010. Cobertura vegetal y uso actual del suelo de la provincia de Loja. Informe Técnico. Departamento de Ciencias de la Información Geográfica de Naturaleza and Cultura internacional. Gráficas Amazonas, Loja.

Garcia-Pichel, F. and J. Belnap. 2001. Small-scale environments and distribution of biological soil crusts. In: J. Belnap and O.L. Lange (eds.), Biological Soil Crusts: Structure, Function, and Management. Springer-Verlag, Berlin. pp. 193-201.

Gauslaa, Y. and K.A. Solhaug. 2001. Fungal melanins as a sun screen for symbiotic green algae in the lichen Lobaria pulmonaria. Oecologia 126: 462-471.

Gorelick, R. 2006. Combining richness and abundance into a single diversity index using matrix analogues of Shannon's and Simpson's indices. Ecography 29: 525-530.

Goward, T., B. Goffinet and O. Vitikainen. 1995. Synopsis of the genus Peltigera (lichenized Ascomycetes) in British Columbia, with a key to the North American species. Can. J. Bot. 73: 91111.

Gradstein, S.R., G.B.A. Van Reenen and D. Griffin III. 1989. Species richness and origin of the bryophyte flora of the Colombian Andes. Acta Bot. Neerl. 38: 439-448.

Gradstein, S.R., S.P. Churchill and N. Salazar. 2001. Guide to the Bryophytes of Tropical America. Memoirs of the New York Botanical Garden. Vol. 86. New York Botanical Garden Press, New York.

Gradstein, S.R. and D.P. Costa. 2003. The Hepaticae and Anthocerotae of Brazil. Memoirs of the New York Botanical Garden. Vol. 87. New York Botanical Garden Press, New York.

Gradstein, S.R. and I. Holz. 2005. Briófitas de los páramos de Costa Rica. In: M. Kappelle, and S.P. Horn (eds.), Páramos de Costa Rica. Editorial INBio, Costa Rica. pp. 361-374.

Grau, O., J.A. Grytnes and H.J.B Birks. 2007. A comparison of altitudinal species richness patterns of bryophytes with other plant groups in Nepal, Central Himalaya. J. Biogeogr. 34: 1907-1915.

Grytnes, J.A. and O.R. Vetaas. 2002. Species richness and altitude: a comparison between null models and interpolated plant species richness along the Himalayan altitudinal gradient, Nepal. Am. Nat. 159: 294-304.

Grytnes, J.A., E. Heegaard and P.G. Ihlen. 2006. Species richness of vascular plants, bryophytes, and lichens along an altitudinal gradient in western Norway. Acta Oecol. 29: 241-246. 
Hauck, M., C. Dulamsuren and M. Mühlenberg. 2007. Lichen diversity on steppe slopes in the northern Mongolian mountain taiga and its dependence on microclimate. Flora 202: 530-546.

Hofstede, R., R. Coppus, P. Mena Vásconez, P. Segarra, J. Wolf and J. Sevink. 2002. El estado de conservación de los páramos de pajonal en el Ecuador. Ecotropicos 15: 3-18.

Hofstede, R., P. Segarra and P. Mena Vásconez. 2003. Los Páramos del Mundo. Global Peatland Initiative/NC-IUCN/EcoCiencia, Quito.

Jankowski, J.E., C.L. Merkord, W. Farfan Rios, K. García Cabrera, N. Salinas Revilla and M.R. Silman. 2013. The relationship of tropical bird communities to tree species composition and vegetation structure along an Andean elevational gradient. $J$. Biogeogr. 40: 950-962.

Kappen, L. 2000. Some aspects of the great success of lichens in Antarctica. Antarct. Sci. 12: 314-324.

Keating, P. 1999. Changes in páramo vegetation along an elevation gradient in southern Ecuador. J. Torrey Bot. Soc. 126: 159-175.

Kessler, M. 2000. Altitudinal zonation of Andean cryptogam communities. J. Biogeogr. 27: 275-282.

Kessler, M. 2002. The elevational gradient of Andean plant endemism: varying influences of taxon-specific traits and topography at different taxonomic levels. J. Biogeogr. 29: 1159-1165.

Krömer, T., M. Kessler, S.R. Gradstein and A. Acebey. 2005. Diversity patterns of vascular epiphytes along an elevational gradient in the Andes. J. Biogeogr. 32: 1799-1809.

Kranner, I., R. Beckett, A. Hochman and T.H. Nash III. 2008 Desiccation-tolerance in lichens: a review. Bryologist 111: 576593

León-Yánez, S. 2000. La Flora de los páramos ecuatorianos. In: C. Josse, P. Mena Vásconez and G. Medina (eds.), La Biodiversidad de los Páramos. Serie Páramo 7. GTP/ Abya Yala, Quito. pp. 6-23.

Lomolino, M.V. 2001. Elevation gradients of species-density: historical and prospective views. Glob. Ecol. Biogeogr. 10: 3-13.

Lücking, R., M. Dal-Forno, J.D. Lawrey, F. Bungartz, M.E. Holgado, J.E. Hernández, M. Marcelli, B. Moncada, E.A. Morales, M.P. Nelsen, E. Paz, L. Salcedo, A.A. Spielmann, K. Wilk, S. WillWolf and A. Yánez Ayabaca. 2013. Ten new species of lichenized Basidiomycota in the genera Dictyonema and Cora (Agaricales: Hygrophoraceae), with a key to all accepted genera and species in the Dictyonema clade. Phytotaxa 139: 1-38.

Lumbsch, H.T. 1989. Die holarktischen Vertreter der Flechtengattung Diploschistes (Thelotremataceae). J. Hattori Bot. Lab. 66: 133 196.

Luteyn, J.L. 1992. Páramos: why study them? In: H. Balslev and J.L. Luteyn (eds.), Páramo: An Andean Ecosystem under Human Influence. Academic. Press, London. pp. 1-14.

Madrinán, S., A.J. Cortés and J.E. Richardson. 2013. Páramo is the world's fastest evolving and coolest biodiversity hotspot. Front. Genet. 4: 1-7.

Maestre, F.T., C. Escolar, I. Martínez and A. Escudero. 2008. Are soil lichen communities structured by biotic interactions? A null model analysis. J. Veg. Sci. 19: 261-266.

Maestre, F.T., I. Martínez, C. Escolar and A. Escudero. 2009. On the relationship between abiotic stress and co-occurrence patterns: an assessment at the community level using soil lichen communities and multiple stress gradients. Oikos 118: 1015-1022.

Magurran, A. 2004. Measuring Biological Diversity. Backwell Publishing. Oxford.

Malhi, Y., M. Silman, N. Salinas, M. Bush, P. Meir and S. Saatchi. 2010. Introduction: elevation gradients in the tropics: laborato- ries for ecosystem ecology and global change research. Glob. Change Biol. 16: 3171-3175.

Mandl, N.A., M. Kessler and S.R. Gradstein. 2009. Effects of environmental heterogeneity on species diversity and composition of terrestrial bryophyte assemblages in tropical montane forests of southern Ecuador. Plant Ecol. Divers. 2: 313-321.

Ministerio del Ambiente Ecuador. 2010. Representación cartográfica de los Ecosistemas del Ecuador Continental. Informe técnico. Quito.

Moncada, B. 2012. El género Sticta (Schreb.) Ach. en Colombia: taxonomía, ecogeografia e importancia (Doctoral dissertation). Universidad Nacional de Colombia.

Myers, N., R.A. Mittermeier, C.G. Mittermeier, G.A.B. da Fonseca and J. Kent. 2000. Biodiversity hotspots for conservation priorities. Nature 403: 853-858.

Nash III, T.H., B.D. Ryan, P. Diederich, C. Gries and F. Bungartz 2002. Lichen Flora of the Greater Sonoran Desert Region. Vol. I. Thomson-Shore, Inc., Dexter, Michigan.

Nash III, T.H., B.D. Ryan, P. Diederich, C. Gries and F. Bungartz 2004. Lichen Flora of the Greater Sonoran Desert Region. Vol. II. Thomson-Shore, Inc., Dexter, Michigan.

Paredes, T. 2006. Macrolichens of the Ecological Reserve Páramo El Angel and the Guandera Biological Station. Lyonia 9: 67-73.

Pérez, F.L. 1997. Microbiotic crusts in the high equatorial Andes, and their influence on paramo soils. Catena 31: 173-198.

Podwojewski, P. and J. Poulenard. 2000. Los suelos de los páramos del Ecuador. In: P. Mena Vásconez, C. Josse and G. Medina (eds.), Los Suelos del Páramo. Serie Páramo 5. GTP/Abya Yala, Quito. pp. 7-26.

Ponzetti, J.M. and B.P. McCune 2001. Biotic soil crusts of Oregon's shrub steppe: community composition in relation to soil chemistry, climate, and livestock activity. Bryologist 104: 212-225.

Rahbek, C. 1995. The elevational gradient of species richness: a uniform pattern? Ecography 18: 200-205.

Rahbek, C. 1997. The relationship among area, elevation, and regional species richness in neotropical birds. Am. Nat. 149: 875-902.

Rai, H., P. Nag, D.K. Upreti and R.K. Gupta. 2010. Climate warming studies in alpine habitats of Indian Himalaya, using lichen based passive temperature-enhancing system. Nat. Sci. 8: 104-106.

Rai, H., R. Khare, C.B. Baniya, D.K Upreti and R.K. Gupta. 2015. Elevational gradients of terricolous lichen species richness in the Western Himalaya. Biodivers. Conserv. 24: 1155-1174.

Rincón-Espitia, A. and N. Mateus. 2013. Morphological and anatomical characterization of the genus Stereocaulon Hoffmann (Lichenized Ascomycetes) in Colombia. Caldasia 35: 241-260.

Rivas Plata, E., R. Lücking, H.J.M. Sipman, A. Mangold, K. Kalb and T. Lumbsch. 2010. A world-wide key to the thelotremoid Graphidaceae, excluding the Ocellularia-MyriotremaStegobolus clade. Lichenologist 42: 139-185.

Sipman, H.J.M. 1989. Lichen zonation in the Parque Los Nevados transect. In: T. van der Hammen, S. Díaz-Piedrahita and V.J. Alvarez (eds.), Studies on Tropical Andean Ecosystems. 3. Crammer, Berlin. pp. 461-483.

Sipman, H.J.M. 1997. Key to lichens with podetia (incl. pseudopodetia) (genera Baeomyces, Cladia, Cladina, Cladonia, Dibaeis Phyllobaeis) for the highlands of Ecuador (above $2500 \mathrm{~m}$ ) with chemical guide to the Cladina and Cladonia species. (On line). Botanic Garden and Botanical Museum Berlin-Dahlem. Free University of Berlin. http://www.bgbm.org/sipman/keys/ Ecuclad.htm

Sipman, H.J.M. 2002. Key to the Stereocaulon species in the Neotropics (On line). Botanic Garden and Botanical Museum 
Berlin-Dahlem. Free University of Berlin. http://www.bgbm. org/sipman/keys/Neostereo.htm

Sklenář, P. and P. Ramsay. 2001. Diversity of zonal páramo plant communities in Ecuador. Divers. Distrib. 7: 113-124.

Sklenář, P., P. Kovár, Z. Palice, D. Stancik and Z. Soldán. 2010. Primary succession of high-altitude Andean vegetation on lahars of Volcán Cotopaxi, Ecuador. Phytocoenologia 40: 15-28.

Smith, J.M.B. and A.M. Cleef. 1988. Composition and origins of the world's tropicalpine floras. J. Biogeogr. 15: 631-645.

Smith, C.W., A. Aptroot, B.J. Coppins, A. Fletcher, O.L. Gilbert, P.W. James and P.A. Wolseley. 2009. The Lichens of Great Britain and Ireland. Natural History Museum Publications, London.

Soto-Medina, E.A. 2013. Patterns of species richness of family Cladoniaceae in the Neotropics. Cryptogamie Mycol. 34: 137148.

Stehn, S.E., C.R. Webster, J.M. Glime and M.A. Jenkins. 2010. Elevational gradients of bryophyte diversity, life forms, and community assemblage in the southern Appalachian Mountains. Can. J. For. Res. 40: 2164-2174.

Stevens, G.C. 1992. The elevational gradient in altitudinal range: an extension of Rapoport's latitudinal rule to altitude. Am. Nat. 140: 893-911.

Sun, S-Q., Y-H. Wu, G-X. Wang, J. Zhou, D. Yu, H-J. Bing and J. Luo. 2013. Bryophyte species richness and composition along an altitudinal gradient in Gongga Mountain, China. PLoS ONE 8: e58131.

Terborgh, J. 1977. Bird species diversity on an Andean elevational gradient. Ecology 58: 1007-1019.

Thompson, D.B., L.R. Walker, F.H. Landau and L.R. Stark. 2005. The influence of elevation, shrub species, and biological soil crust on fertile islands in the Mojave Desert, USA. J. Arid Environ. 61: 609-629.
Tusiime, F.M., S.M. Byarujali and J.W. Bates. 2007. Diversity and distribution of bryophytes in three forest types of Bwindi Impenetrable National Park, Uganda. Afr. J. Ecol. 45: 79-87.

Valencia, R., C. Cerón, W. Palacios and R. Sierra. 1999. Las formaciones naturales de la Sierra del Ecuador. In: R. Sierra (ed.), Propuesta preliminar de un sistema de clasificación de vegetación para el Ecuador continental. Proyecto INEFAN/GEFBIRF y EcoCiencia, Quito. pp. 79-114.

Van Reenen, G.B.A. and S.R. Gradstein. 1983. Studies on Colombian cryptogams XX. A transect analysis of the bryophyte vegetation along an altitudinal gradient on the Sierra Nevada de Santa Marta, Colombia. Acta Bot. Neerl. 32: 163-175.

Vittoz, P., M. Camenisch, R. Mayor, L. Miserere, M. Vust and J-P. Theurillat. 2010. Subalpine-nival gradient of species richness for vascular plants, bryophytes and lichens in the Swiss Inner Alps. Bot. Helv. 120: 139-149.

Walker, M.D., C.H. Wahren, R.D. Hollister, G.H.R. Henry, L.E. Ahlquist, J.M. Alatalo, M.S. Bret-Harte, M.P. Calef, T.V. Callaghan, A.B. Carroll, H.E. Epstein, I.S. Jónsdóttlr, J.A. Klein, B. Magnússon, U. Molau, S.F. Oberbauer, S.P. Rewa, C.H. Robinson, G.R. Shaver, K.N. Sudlng, C.C. Thompson, A. Tolvanen, Ø. Totland, P.L. Turner, C.E. Tweedle, P.J. Webber and P.A. Wookey. 2006. Plant community responses to experimental warming across the tundra biome. Proc. Natl. Acad. Sci. U.S.A., 103: $1342-1346$.

Received May 16, 2016

Revised October 6, December 6, 2016

Accepted December 9, 2016

\section{Electronic supplement}

Number of sampling units and mean cover on which each species appear in each of the five páramos. The file may be downloaded from www.akademiai.com. 